\title{
Antihistamin terbaru dibidang dermatologi
}

\author{
Fesdia Sari ${ }^{1}$, Satya Wydya Yenny²
}

\begin{abstract}
Abstrak
Antihistamin merupakan obat yang sering dipakai dibidang dermatologi, terutama untuk kelainan kronik dan rekuren. Antihistamin adalah zat yang dapat mengurangi atau menghalangi efek histamin terhadap tubuh dengan jalan memblok reseptor histamin. Bilastine dan rupatadine merupakan dua buah antihistamin terbaru yang dipakai dibidang dermatologi. Bilastin termasuk antagonis reseptor $\mathrm{H} 1$ generasi kedua terbaru yang paling aman dan tidak memiliki efek terhadap kardiovaskuler. Rupatadin adalah antihistamin $\mathrm{H} 1$ generasi kedua terbaru selain memiliki efek terhadap histamin juga memiliki efek terhadap platelet activating factor.
\end{abstract}

Kata kunci: antihistamin, bilastin, rupatadin

\begin{abstract}
Antihistamine is a drug often used in dermatology, especially for chronic and recurrent disorders. Antihistamines are substances that can reduce or block the effects of histamine on the body by blocking histamine receptors. Bilastine and rupatadine are the two most recent antihistamines used in dermatology. Bilastine is the newest second generation $\mathrm{H} 1$ receptor antagonist that is safest and has no effect on cardiovascular. Rupatadin is the newest second generation $H 1$ antihistamine in addition to having an effect on histamine also has an effect on platelet activating factor.
\end{abstract}

Keywords: antihistamine, bilastine, rupatadine

Affiliasi penulis : 1. Pendidikan Dokter Spesialis Kulit dan Kelamin RSUP Dr. M. Djamil Padang, 2. Bagian Kulit dan Kelamin RSUP Dr. M. Djamil Padang

Korespondensi : Fesdia Sari, Bagian Kulit dan Kelamin RSUP Dr. M. Djamil Padang dia_fs@yahoo.com

\section{PENDAHULUAN[Subject]}

Antihistamin merupakan obat yang sering dipakai dibidang dermatologi, terutama untuk kelainan kronik dan rekuren. Antihistamin adalah zat yang dapat mengurangi atau menghalangi efek histamin terhadap tubuh dengan jalan memblok reseptor histamin. Antihistamin dan histamin berlomba untuk menempati reseptor yang sama. Ada empat tipe reseptor histamin, yaitu $\mathrm{H} 1, \mathrm{H} 2, \mathrm{H} 3$, dan $\mathrm{H} 4$ yang keempatnya memiliki fungsi dan distribusi yang berbeda. Pada kulit manusia hanya reseptor $\mathrm{H} 1$ dan $\mathrm{H} 2$ yang berperan utama. Blokade reseptor oleh antagonis $\mathrm{H} 1$ menghambat terikatnya histamin pada reseptor sehingga menghambat dampak akibat histamin misalnya kontraksi otot polos, peningkatan permeabilitas pembuluh darah dan vasodilatasi pembuluh darah. ${ }^{1}$

Histamin memiliki peranan yang penting dalam patofisiologi penyakit alergi. Histamin adalah amina dasar yang dibentuk dari histidin oleh histidine dekarboksilase. Histamin ditemukan pada semua jaringan, tetapi memiliki konsentrasi yang tinggi pada jaringan yang berkontak dengan dunia luar, seperti paru-paru, kulit, dan saluran pencernaan. ${ }^{2}$ Urtikaria dan rhinitis alergi merupakan dua penyakit alergi yang sering menyebabkan gangguan pola tidur dan mempengaruhi aktivitas sehari-hari. Pada kondisi yang berat, kelainan ini dapat mempengaruhi kualitas hidup seseorang, mulai dari gangguan fisik, gangguan emosional, gangguan aktivitas seksual, terbatasnya aktivitas sosial, dan mempengaruhi pekerjaan. ${ }^{3,4}$ Angka kejadian urtikaria kronis diperkirakan 0,1-3\% dari keseluruhan populasi di Eropa dan Amerika. Di dunia prevalensinya diperkirakan sekitar $0,5 \%$ dan angka ini tidak berbeda secara signifikan pada komunitas yang berbeda. ${ }^{3}$ Di seluruh dunia diperkirakan $12 \%$ sampai $22 \%$ orang pernah mengalami gejala urtikaria sekurang-kurangnya satu kali selama hidup. Salah satu golongan obat yang selalu dipakai dalam penanganan urtikaria adalah antihistamin. ${ }^{2}$ Difendramin merupakan obat yang pertama kali digunakan, yang efektif pada urtikaria kronis. ${ }^{5,6}$

\section{PEMBAHASAN}

\section{Definisi}

Antihistamin (antagonis histamin adalah zat yang dapat mengurangi atau menghalangi efek histamin terhadap tubuh dengan jalan memblokir reseptor histamin. Histamin merupakan derivat amin dengan berat molekul rendah yang diproduksi dari L-histidine. Ada empat jenis reseptor histamin, namun yang dikenal secara luas hanya reseptor histamin $\mathrm{H}_{1}$ dan $\mathrm{H}_{2}$. Reseptor $\mathrm{H}_{1}$ ditemukan pada neuron, otot polos, epitel dan endotelium. Reseptor $\mathrm{H}_{2}$ ditemukan pada sel parietal mukosa lambung, otot polos, epitelium, endotelium, dan jantung. Sementara reseptor $\mathrm{H}_{3}$ dan $\mathrm{H}_{4}$ ditemukan dalam jumlah yang terbatas. Reseptor $\mathrm{H}_{3}$ terutama ditemukan pada neuron histaminergik, dan reseptor $\mathrm{H}_{4}$ ditemukan pada sum-sum tulang dan sel hematopoitik perifer. ${ }^{4}$ 
Istilah antihistamin pertama kali ditujukan pada reseptor antagonis $\mathrm{H}_{1}$ yang digunakan untuk terapi penyakit inflamasi dan alergi. Antagonis reseptor $\mathrm{H}_{1}$ dapat dibagi menjadi generasi pertama dan generasi kedua. ${ }^{1}$

\section{Antihistamin terbaru}

Antihistamin $\mathrm{H} 1 \quad$ generasi kedua lebih direkomendasikan dalam penanganan urtikaria kronis karena lebih aman pada pemakaian jangka lama. Pada beberapa tahun belakangan dikenal beberapa antihistamin $\mathrm{H} 1$ generasi kedua yang baru, yaitu Bilastine dan Rupatadine. Kedua antihistamin baru ini memiliki keunggulan masing-masing dibandingkan antihistamin generasi kedua sebelumnya. Bilastine merupakan antihistamin $\mathrm{H} 1$ paling aman terhadap kardiovaskuler, dan Rupatadine selain juga aman terhadap kardiovakuler, juga memilki efek terhadap platelet activating factor. ${ }^{6,7}$

Bilastin

Bilastine merupakan antihistamin $\mathrm{H} 1$ yang baru dikenal luas dalam terapi rhinokonjungtivitis dan urtikaria pada dewasa dan anak-anak diatas 12 tahun. Bilastine tidak dimetabolisme di hati, relatif aman, tidak menyebabkan efek kolinergik dan tidak menyebabkan perubahan yang signifikan pada pemeriksaan laboratorium, vital sign, dan gelombang EKG. Penelitian klinis menunjukkan bilastine dengan dosis $20 \mathrm{mg} / \mathrm{hari}$ sama efektifnya dengan levocetirizin pada urtikaria kronik..$^{8,9}$ Bilastin digunakan di Uni Eropa tahun 2010 dan telah di gunakan di 28 negara di Eropa. ${ }^{10}$

Bilastin atau 2-[4-[2-[4-[1-(2-ethoxyethyl) benzimidazol-2-yl]piperidin-1-yl]ethyl]phenyl]-2-

methylpropionic acid memiliki struktur kimia binzimidazole piperidinyl dengan berat molekul 463,6 daltons. Struktur Bilastin tidak berasal dari antihistamin lain, tidak juga metabolit atau enansiomer dari antihistamin lainnya. Struktur kimia dari bilastin hampir sama dengan piperidinyl-benzimidazole. ${ }^{11,12}$

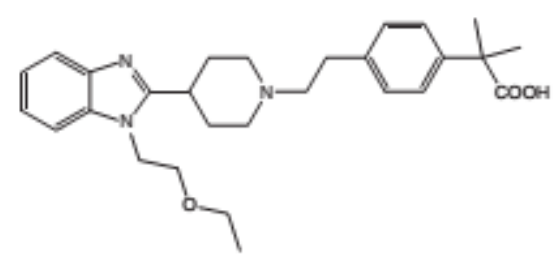

Gambar 1. Struktur kimia dari bilastin 8

Sama dengan antihistamin lainnya, Bilastin merupakan antagonis reseptor $\mathrm{H}_{1}$. Bilastin berikatan dengan reseptor $\mathrm{H}_{1}$ dengan afinitas sama dengan astemizol dan diphenhydramin, dan lebih kuat dari cetirizin dan fexofenadin. Pada isolasi organ hewan percobaan (ileum dan trakea) potensi antihistamin invitro lebih kuat dari cetirizin dan fexofenadin. Bilastin bekerja lebih selektif pada reseptor $\mathrm{H} 1$, dan sedikit bahkan tidak ada pada reseptor $\mathrm{H} 2, \mathrm{H} 3, \mathrm{H} 4$, muskarinik, $\alpha 1$-dan $\beta 2$ adrenergik, bradikinin $\mathrm{B} 1$,
Leukotrien D4 dan reseptor calcium. Percobaan pada tikus menunjukkan efek Bilastin tergantung dosis, bekerja panjang, dan aktivitasnya lebih kuat dari cetirizin. ${ }^{13,14}$

Bilastin oral diabsorbsi dengan cepat dalam kondisi puasa, dengan konsentrasi puncak dalam plasma $220 \mathrm{ng} / \mathrm{ml}$ sekitar satu jam setelah dosis tunggal dan multipel. Bioavailabilitas oral diperkirakan rata-rata $61 \%$. Absorbsi dihambat oleh sarapan yang berlemak atau jus buah. 13,14 Oleh karena itu pemberian Bilastin direkomendasikan satu jam sebelum makan atau 2 jam setelah makan. Pada dosis terapi Bilastin berikatan dengan protein plasma sekitar $84-90 \% .13,15$

Bilastin tidak dimetabolisme di sel hati manusia dan tidak menghambat atau menginduksi aktivitas enzim sitokrom P450. Bilastin di eliminasi dengan lambat dan waktu paruh 10-14 jam, dan 96\% dari obat dieliminasi dalam waktu 24 jam. 9,13

Pemberian bilastin bersamaan dengan jus anggur mengurangi efek sistemik Bilastin secara signifikan. Interaksi ini kemungkinan disebabkan oleh efek flavonoid pada sistem transpor di usus sebagai $P$ gp dan peptida transpor anion organik. Pemberian Bilastin bersamaan dengan Ketokonazol (dikenal inhibitor sitokrom P450-3A4 dan inhibitor P-gp) untuk beberapa hari, kadar sistemik Bilastin meningkat 2 kali lipat. 9,14

Pemberian Bilastin dengan dosis 40mg dapat menyebabkan mengantuk, tetapi tidak terbukti secara objektif. Pemberian dengan dosis $80 \mathrm{mg}$ (4kali diatas dosis yang direkomendasikan) menyebabkan gangguan psikomotor. Dan pemberian Bilastin dengan dosis $20 \mathrm{mg}$ terbukti aman dan tidak ada efek terhadap susunan saraf pusat. 9,13

Pada penelitian, Bilastin 20mg tidak meningkatkan efek depresi susunan saraf pusat pada pemberian bersamaan dengan lorazepam $3 \mathrm{mg}$. Bilastin juga tidak berinteraksi dengan alkohol.9,14 Pemberian Bilastin dosis tunggal dengan dosis sampai $220 \mathrm{mg}$ dan pemberian multipel sampai dengan dosis $200 \mathrm{mg}$ selama 7 hari tidak memilki efek yang signifikan terhadap prolong interval gelombang QT, repolarisasi ventrikel. ${ }^{12,13}$ Bilastin merupakan antihistamin $\mathrm{H}_{1}$ paling aman terhadap kardiovaskuler diantara semua antihistamin yang ada. ${ }^{14}$

\section{Bilastin pada urtikaria kronis}

Pada penelitian pemberian Bilastin dengan dosis $20 \mathrm{mg}$ dan $50 \mathrm{mg}$ dalam mengurangi edem dan flare yang disebabkan histamin ekuivalen atau superior dari cetirizin (mengambat $>50 \%$ dalam 12 jam). Dalam waktu 1,5 jam setelah pemberian $20 \mathrm{mg}$ Bilastin atau cetirizin $10 \mathrm{mg}$, udem dan flare berkurang, tetapi dengan Bilastin persentase hambatannya jauh lebih besar. Setelah 24 jam pemberian, hanya Bilastin $50 \mathrm{mg}$ yang dapat menghambat edem $>50 \%{ }^{9}$ 


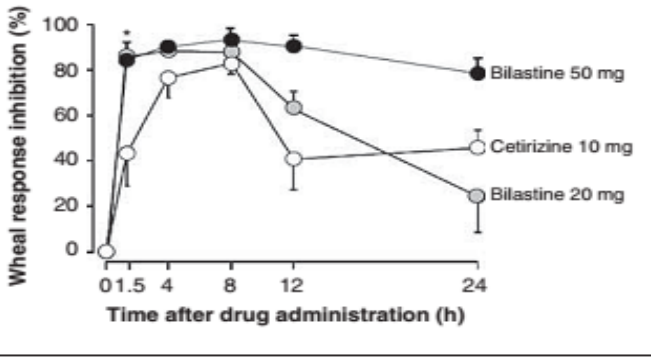

Gambar. 2. Hambatan area dari edem yang diinduksi histamin oleh cetirizin $10 \mathrm{mg}$, bilastine $20 \mathrm{mg}$, bilastin $50 \mathrm{mg} .^{9}$

Pada penelitian yang dilakukan terhadap 218 pasien urtikaria kronis, diberikan Bilastin $10 \mathrm{mg}, 20 \mathrm{mg}$, $30 \mathrm{mg}$, dan plasebo. Semua dosis Bilastin lebih kuat dari plasebo dalam mengurangi gejala urtikaria, dengan mengukur gatal dan jumlah serta diameter edem yang dievaluasi pada pasien dua kali sehari selama 28 hari. ${ }^{9}$

Pada penelitian lain yang dilakukan pada 516 pasien dengan utikaria kronis, diberikan Bilastin 20mg, levocetirizin $5 \mathrm{mg}$, dan plasebo selama 28 hari, kemudian diukur rasa gatal, jumlah edem dan diameter edem terdapat perbedaan yang bermakna dari obat aktif dibandingkan plasebo. Tetapi tidak ada perbedaan yang bermakna dari Bilastin dan Levocetirizin. ${ }^{9}$

Rupatadin

Rupatadin merupakan salah satu antihistamin $\mathrm{H} 1$ non sedatif yang modern, dimana juga mempunyai efek tambahan berupa antagonis platelet activating factor (PAF). Secara komersial Rupatadin tersedia dalam bentuk sediaan tablet $10 \mathrm{mg}$ di Spanyol dan beberapa negara eropa lainnya. Di Jerman Rupatadin digunakan untuk terapi rinitis dan urtikaria kronik pada dewasa dan anak-anak lebih dari 12 tahun dengan nama dagang Rupafin sejak 1 Agustus 2008 dan Urtimed sejak tahun $2010{ }^{6}$

Struktur kimia Rupatadin adalah Rupatadine (8-chloro-11-[1-[5-methyl-3-pyridinyl)methyl]piperidin4-ylidene]-6,11-dihydro-5H-benzo[5,6]cycloheptal 1,2b]pyridine fumarate). Rupatadin berikatan lebih selektif dengan reseptor $\mathrm{H} 1$ di jaringan paru dibandingkan di jaringan otak (serebelum) setelah pemberian oral 0,16 $\mathrm{mg} / \mathrm{kg}$ pada hewan percobaan. ${ }^{15}$

Penelitian menggunakan enzim mikrosom hati manusia menunjukkan bahwa sitokrom P450 CYP3A4 merupakan isoenzim utama yang bertanggung jawab dalam biotransformasi Rupatadin. ${ }^{16}$

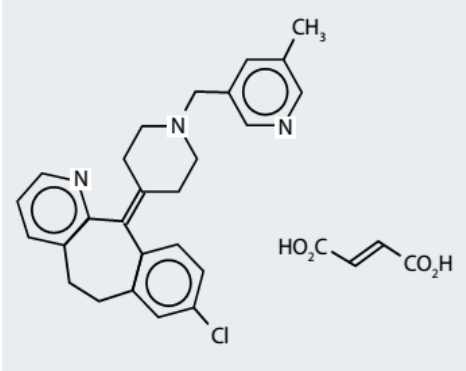

Gambar 3. Struktur Kimia Rupatadin 6

Konsentrasi maksimum plasma Rupatadin 2,3ng/ml pada dewasa dicapai setelah 45 menit sampai dengan 1 jam secara oral. Waktu paruh Rupatadin 5,9 jam setelah mengalami metabolisme presistemik ketika dikonsumsi secara oral. Jalur biotransformasi yang paling penting dari Rupatadin adalah proses oksidatif, oksidasi dari grup pyridine-methyl menjadi asam karboksilik, $\mathrm{N}$-dealkylation dari piperidine nitrogen dan hidroksilasi dari posisi 3-,5- dan 6- dari sistem ring trisiklik. Rupatadin ditemukan dalam urin dan feses dalam jumlah yang sedikit. Rupatadin berikatan dengan protein plasma 98\%-99\%. Meskipun angka berikatan Rupatadin tinggi, ia tetap didistribusikan dengan baik dan mencapai reseptor target. Penelitian menunjukkan konsentrasi plasma maksimum dari substansi aktif tertunda sekitar 1 jam ketika diberikan bersama makanan, namun walaupun tertunda, konsentrasi maksimum di darah tidak mengalami perubahan oleh makanan. ${ }^{6}$

Rupatadin memiliki potensi berinteraksi dengan obat lain yang dimetabolisme melalui jalur mikrosomal oksidatif dan melibatkan enzim CYP3A4. Penelitian membuktikan pemberian rupatadin bersama ketokonazol dan eritromisin meningkatkan efek sistemik dari rupatadin tetapi tidak ada efek terhadap EKG pasien. ${ }^{6}$

Penelitian lain membuktikan tidak ada interaksi antara pemberian Rupatadin bersamaan dengan fluoxetin (substrat dari CYP2D6) atau etanol. Pemberian bersamaan dengan Azitromisin (substrat $P$ glycoprotein saluran percernaan) tidak menunjukkan interaksi yang bermakna dan Rupatadin juga tidak mempotensiasi efek depresi susunan saraf pusat dari Lorazepam. Berdasarkan interaksi ini, pemberian Rupatadin harus hati-hati bersamaan dengan obat yang menghambat CYP3A4, seperti antibiotik makrolid dan anti jamur golongan azol. ${ }^{17}$

Rupatadin juga memiliki aktivitas antagonis platelet activating factor. Platelet activating factor adalah salah satu fosfolipid endogen yang memediasi inflamasi dan dibentuk oleh sel inflamasi seperti makrofag alveolar, eosinofil, sel mast, basofil, platelet dan netrofil yang dikeluarkan sebagai respon terhadap reaksi alergi/inflamasi. Reaksi ini berhubungan dengan peningkatan permeabilitas vaskular, kemoatraksi eosinofil, bronkokonstriksi, hiperresponsif jalur nafas, dimana semua ini terlibat dalam patofisiologi rinitis, asma dan anafilaksis. Tambahan lagi, peningkatan level plasma dari PAF dilaporkan juga pada pasien urtikaria dan psoriasis dibandingkan dengan orang sehat. Aktivitas anti PAF Rupatadin lebih rendah dari antagonis spesifik PAF WEB-2086 dan Ginkgolid B, tetapi lebih tinggi dibandingkan antihistamin loratadin, ketotifen, mepyramine, cetirizin atau terfenadin. ${ }^{6}$

Berbeda dari antihistamin generasi pertama, rupatadin tidak memilki efek antikolinergik pada pemberian dosis tunggal $10-80 \mathrm{mg} .{ }^{15}$ Efek terhadap kardiovaskuler dari rupatadin telah banyak diteliti, lebih 
dari 6000 EKG dari pasien atau sukarela yang mengkonsumsi rupatadin $2,5 \mathrm{mg}$ sampai dengan $80 \mathrm{mg}$ sehari telah dianalisis. Tidak ada perubahan dari interval QT pada EKG, walaupun rupatadin diberikan bersamaan dengan inhibitor CYP3A4. 17,18

\section{Rupatadin pada urtikaria kronis}

Walaupun Rupatadin termasuk salah satu antihistamin yang baru, penggunaannya dalam terapi urtikaria telah banyak diteliti. Pada penelitian dengan 283 pasien urtikaria kronis yang mendapat rupatadin $5 \mathrm{mg}, 10 \mathrm{mg}, 20 \mathrm{mg}$, atau plasebo sekali sehari selama 4 minggu, menunjukkan penurunan skor mean pruritus severity (MPS) yang signifikan pada rupatadin dibandingkan plasebo. Respon terapi, status urtikaria kronis, tidur, dan perfoma aktivitas sehari-hari pasien meningkat pada pemberian rupatadin $10 \mathrm{mg}$ atau $20 \mathrm{mg}$ sehari. Rupatadin $10 \mathrm{mg}$ sehari memiliki efek yang cepat, kerja lama, efektif dan aman untuk managemen urtikaria kronis ringan sampai berat. Pada penelitian ini Rupatadin $10 \mathrm{mg}$ sehari memiliki efek yang cepat, kerja lama, efektif dan aman untuk managemen urtikaria kronis ringan sampai berat. Pada penelitian ini efek dari rupatadin tampak pada minggu pertama dan bertahan pada minggu keempat dan keenam. 6,15

Pada penelitian lain menunjukkan Rupatadin lebih kuat dan aman dibandingkan levocetirizin pada urtikaria kronis. Dari 70 pasien urtikaria kronis, 35 pasien diterapi dengan rupatadin $10 \mathrm{mg}$ sehari dan 35 pasien diterapi dengan levocetirizin $5 \mathrm{mg}$ sehari selama 4 minggu. Pada kelompok rupatadin, terdapat penurunan yang bermakna secara statistik dari eosinofil, serum IgE, total symptom score, dan Aerius Quality of Life Questionnaire. ${ }^{6,15}$

\section{SIMPULAN}

Bilastin dan Rupatadine merupakan antihistamin terbaru yang dapat digunakan dalam penanganan urtikaria kronis. Bilastin merupakan antihistamin $\mathrm{H}_{1}$ generasi kedua terbaru yang aman dan tidak memiliki efek terhadap kardiovaskuler. Rupatadin merupakan antihistamin $\mathrm{H}_{1}$ generasi kedua terbaru selain memiliki efek terhadap histamin juga memiliki efek terhadap platelet activating factor.

\section{DAFTAR PUSTAKA}

1. Wood A. Antihistamines. Dalam: Wolff K, Goldsmith LA, Katz SI, Gilchrest BA, Paller AS, Leffel DJ, penyunting. Fitzpatrick's dermatology in general medicine. Edisi ke-8. New York: McGraw Hill companies; 2012.h.439-448.

2. Ortonne J. Urticaria and its subtypes: The role of second-generation antihistamines. Euro $\mathrm{J}$ of Int Med. 2012;23(1):26-30.

3. Mullol J, Bousquet J, Bachert C, Canonina W, Gimenez A, Kowalski ML. Update on rutapadine in the management of allergic disorders. Euro $\mathrm{J}$ of Aller and Clin Immun. 2014;70:1-24.
4. Greaves M. Antihistamines in Dermatology. Skin Pharmacol Physiol. 2005;18(5):220-229.

5. Zuberbier T. Pharmacological rationale for the treatment of chronic urticaria with secondgeneration non-sedating antihistamines at higher-than-standard doses. J of the Euro Aca of Dermatol and Venereo. 2011;26(1):9-18.

6. Shamizadeh S, Brockow K, Ring J. Rupatadine: efficacy and safety of a nonsedating antihistamine with PAF-antagonist effects. Allergo J Int. 2014;23(3):87-95.

7. García-Gea C, Martínez J, Ballester M, Gich I, Valiente R, Antonijoan R. Psychomotor and subjective effects of bilastine, hydroxyzine, and cetirizine, in combination with alcohol: a randomized, double-blind, crossover, and positive-controlled and placebo-controlled Phase I clinical trials. Human Psychopharmacology: Clinical and Experimental. 2014;29(2):120-132

8. Jáuregui I, Ramaekers J, Yanai $\mathrm{K}$, Farré $\mathrm{M}$, Redondo E, Valiente R, et al. Bilastine: a new antihistamine with an optimal benefit-to-risk ratio for safety during driving. Expert Opinion on Drug Safety. 2015;15(1):89-98

9. Auregui I, Ferrer M, Bartra J, Del Cuvillo A, Dávila I, Montoro J, et al. Bilastine for the treatment of urticaria. Expert Opinion on Pharmacotherapy. 2013;14(11):1537-1544.

10. Scaglione G. Safety profile of Bilastine: second generation $\mathrm{H} 1$ antihistamines. European Review for medical and Pharmacological Science.2012;16:19992005.

11. Ridolo E, Montagni M, Bonzano L, Incorvaia C, Canonica G. Bilastine: new insight into antihistamine treatment. Clinical and Molecular Allergy. 2015;13(1):1-6. .

12. Lasseter K, Sologuren A, La Noce A, Dilzer S. Evaluation of the single-dose pharmacokinetics of bilastine in subjects with various degrees of renal insufficiency. Clinical Drug Investigation. 2013;33(9):665-673.

13. Farré $M$, Pérez-Mañá $C$, Papaseit $E$, Menoyo $E$, Pérez M, Martin S, et al. Bilastine vs. hydroxyzine: occupation of brain histamine $\mathrm{H}$ 1 -receptors evaluated by positron emission tomography in healthy volunteers. Brit $\mathrm{J}$ of Clin Pharmacol. 2014;78(5):970-980.

14. Mitchell S, Balp M, Samuel M, McBride D, Maurer M. Systematic review of treatments for chronic spontaneous urticaria with inadequate response to licensed first-line treatments. Int J of Dermatol. 2014;54(9):1088-1104.

15. Ridolo E, Montagni M, Fassio F, Massaro I, Rossi O, Incorvaia C, et al. Rupatadine for the treatment of allergic rhinitis and urticaria: a look at the clinical data. Clinical Investigation. 2014;4(5):453-461.

16. Johnson M, Kwatra G, Badyal D, Thomas E. Levocetirizine and rupatadine in chronic idiopathic urticaria. International Journal of Dermatology. 2014;54(10):1199-1204.

17. Metz M, Weller $K$, Neumeister $C$, Izquierdo I, Bödeker R, Schwantes U, et al. Rupatadine in established treatment schemes improves chronic spontaneous urticaria symptoms and patients' quality of life: a prospective, non- 
interventional trial. Dermatol Ther (Heidelb)

2015;5(4):217-230.

18. Abajian $M$, Curto-Barredo L, Krause $K$,

Santamaria E, Izquierdo I, Church M, et al.

Rupatadine $20 \mathrm{mg}$ and $40 \mathrm{mg}$ are effective in

reducing the symptoms of chronic cold

urticaria. Acta Dermato Venereologica.

2016;96(1):56-59. 